\title{
KARAKTERISTIK METAKOGNISI DALAM PEMECAHAN MASALAH MATEMATIKA DITINJAU DARI TIPE KEPRIBADIAN
}

\author{
Syaiful Huda ${ }^{1}$, Dina Agustin², Fatimatul Khikmiyah ${ }^{3}$ \\ ${ }^{1}$ Universitas Muhammadiyah Gresik \\ ${ }^{2}$ Universitas Muhammadiyah Gresik \\ ${ }^{3}$ Universitas Muhammadiyah Gresik \\ ${ }^{1}$ syaifulhuda@umg.ac.id \\ 2dinagustin76@gmail.com \\ fatim@umg.ac.id
}

\begin{abstract}
Someone in solving problems, needs to manage his mind well by utilizing the knowledge he already has, controlling and reflecting on the process and results of his own thinking. Then, what he thinks can help him in solving the problem. This awareness of the thought process is known as metacognition. However, in today's learning system, educators evaluate the achievement of learning outcomes by only emphasizing the goals of cognition without showing the cognitive process, more specifically on metacognitive knowledge and skills. Apart from that, in solving problems students also need characteristics. This research is an exploratory type of research. This study aims to describe the metacognitive characteristics of students in solving problems in terms of the personality types of these students. Of the six personality types, there are dominant personality types, namely social personalities who are taken as research subjects with high, medium, and low levels of metacognitive ability. Characteristics of high and low level metacognition in social personality types have differences that are seen in awareness to identify information that is known and asked. At high levels, social personality types recognize the need for identification so that they are able to plan actions appropriately, but in contrast to low-level metacognition.
\end{abstract}

Keywords: Problem Solving, Metacognition, personality type.

\begin{abstract}
Abstrak
Seseorang dalam melakukan pemecahan masalah, perlu mengelola pikirannya secara baik dengan memanfaatkan pengetahuan yang telah dimiliki, mengontrol dan merefleksi proses serta hasil berpikirnya sendiri. Kemudian, apa yang dipikirkan dapat membantunya dalam menyelesaikan masalah tersebut. Kesadaran terhadap proses berpikirnya ini disebut sebagai metakognisi. Namun dalam sistem pembelajaran masa kini, pendidik melakukan evaluasi pencapaian terhadap hasil belajar dengan hanya memberikan penekanan kepada tujuan kognisi dengan tanpa memperlihatkan proses kognisinya, lebih khusus pada pengetahuan dan keterampilan metakognisi. Selain dari pada itu, dalam memecahkan permasalahan peserta didik juga memerlukan adanya karakteristik. Penelitian ini merupakan penelitian yang berjenis eksploratif. Penelitian ini bertujuan untuk mendeskripsikan karakteristik metakognisi peserta didik dalam memecahkan masalah ditinjau dari tipe kepribadian peserta didik tersebut. Dari enam tipe kepribadian tersebut terdapat tipe kepribadian dominan yaitu kepribadian sosial yang diambil sebagai subjek penelitian dengan tingkat kemampuan metakognisi tinggi, sedang, dan rendah. Karakteristik metakognisi tingkat tinggi dan rendah pada tipe kepribadian social memiliki perbedaan yang terlihat pada kesadaran untuk mengidentifikasi informasi yang diketahui dan ditanya. Pada tingkat tinggi, tipe kepribadian social menyadari perlunya identifikasi sehingga mampu merencanakan tindakan secara tepat, namun berkebalikan dengan metakognisis tingkat rendah.
\end{abstract}

Kata kunci: Pemecahan Masalah, Metakognisi, Tipe Kepribadian.

Cara Menulis Sitasi: Huda, S., Agustin, D., \& Khikmiyah, F. (2021). Karakteristik Metakognisi dalam Pemecahan Masalah Matematika Ditinjau dari Tipe Kepribadian. Mathematic Education and Aplication Journal, volume 3 no. 1, halaman 21-34.

Mulai dari jenjang sekolah dasar sampai menengah atas, salah satu aspek yang paling penting dalam pembelajaran matematika di sekolah adalah kemampuan memecahkan masalah. Menurut Depdiknas 
(2006), tujuan dari pembelajaran matematika di sekolah yaitu untuk 1) melatih pola pikir dan penalaran dalam mengambil kesimpulan, 2) mengembangkan kemampuan dalam memecahkan masalah, dan 3) mengembangkan kemampuan untuk memberikan informasi atau mengkomunikasikan gagasan melalui lisan, diagram, tertulis, grafik, peta, gambar, dan lain-lain. Memecahkan masalah matematika merupakan aktifitas penting di dalam pembelajaran matematika. Pemecahan masalah matematika bisa digunakan sebagai alat mengembangkan kemampuan di dalam membangun pengetahuan yang baru, mengimplementasikan strategi yang dibutuhkan, mengaitkan matematika di berbagai konteks, dan refleksi dari proses pemecahan masalah (Anggo, 2011). Seseorang dalam melakukan pemecahan masalah, perlu mengelola pikirannya secara baik dengan memanfaatkan pengetahuan yang telah dimiliki, mengontrol dan merefleksi proses serta hasil berpikirnya sendiri. Kemudian, apa yang dipikirkan dapat membantunya dalam menyelesaikan masalah tersebut. Kesadaran terhadap proses berpikirnya ini disebut sebagai metakognisi (Purnaningsih \& Siswono, 2014). Metakognisi adalah berfikirnya peserta didik dalam rangka mengetahui bagaimana cara melakukan pendekatan kepada masalahnya, memilah strategi yang digunakan untuk menentukan pemecahan dari masalah dan bertanya pada dirinya sendiri tentang masalah itu (Rachmady, Anggo, \& Busnawir, 2019).

Namun dalam sistem pembelajaran masa kini, pendidik melakukan evaluasi pencapaian terhadap hasil belajar dengan hanya memberikan penekanan kepada tujuan kognisi dengan tanpa memperlihatkan proses kognisinya, lebih khusus pada pengetahuan dan keterampilan metakognisi (Rosiani, Anggo, \& Saudia, 2019). Hal tersebut berakibat upaya dalam memperkenalkan metakognisi dipemecahan masalah matematika kepada peserta didik tentu sangat kurang dan bahkan diabaikan. Lebih jauh, Brown (Lee dan Baylor, 2006) mendefinisikan metakognisi sebagai kesadaran akan aktifitas kognisi individu, penggunaan metode di dalam mengatur proses kognisinya dan suatu penguasaan tentang bagaimana merencanakan, mengarahkan, serta memantau aktifitas kognitifnya. Pendapat ini menekankan bahwa metakognisi sebagai kesadaran terhadap aktifitas kognisi, yang berkaitan dengan bagaimana individu tersebut sadar proses berpikir yang dilakukannya. Kesadaran tersebut menjadi terwujud tergantung bagaimana cara individu mengelola dan mengatur aktifitas berpikirnya. Selain itu menurut Schraw and Dennison (1994), metakognisi didefinisikan sebagai kemampuan untuk merefleksikan, memahami, dan mengontrol kemampuan belajar individu. Sependapat dengannya, Suherman (dalam Mahromah dan Janet, 2013) juga mengatakan bahwa metakognisi adalah kemampuan agar menyadari apa yang individu ketahui tentang dirinya sebagai pebelajar, sehingga individu tersebut dapat mengontrol serta menyesuaikan tindakan/perilakunya secara baik.

Metakognisi mempunyai peran yang penting dalam mengontrol dan mengatur pola pikir individu dalam memecahkan masalah. Sehingga dapat dipahami bahwa metakognisi akan menjadi tumpuan individu dalam memecahkan masalah. Selain dari pada itu, dalam memecahkan permasalahan peserta didik juga memerlukan adanya karakteristik.

Karakteristik individu juga mempunyai peran yang penting di dalam melakukan pemecahan 
masalah. Karakteristik individu terkoneksi dengan kepribadian individu tersebut. Setiap individu berbeda-beda dalam menghadapi masalah sesuai dengan tipe kepribadian masing-masing. Suatu cara untuk membedakannya adalah dengan melihat tipe kepribadian dari setiap individu. Fitria, Sujadi, dan Subanti (2016) menjelaskan bahwa setiap peserta didik memiliki kesulitan tersendiri dalam melakukan metakognisi ketika memecahkan masalah matematika berdasarkan tipe kepribadiannya. Menurut John L. Holland ada 6 tipe kepribadian, yaitu realistis, intelektual, sosial, konvensional, usaha, dan artistic. Dalam hal ini John L. Holland lebih menekankan kepada minat dari peserta didik, sehingga penelitian ini akan ditujukan kepada peserta didik SMK (Sekolah Menengah Kejuruan). Tujuan dari penelitian ini adalah untuk mengetahui proses metakognisi peserta didik di SMK terhadap pemecahan masalah berdasarkan Tipe Kepribadian Holland.

\section{METODE}

Penelitian eksploratif digunakan dalam bertujuan untuk menggali secara luas tentang sebab-sebab ataupun hal-hal yang memiliki pengaruh terjadinya sesuatu. Penelitian ini bertujuan untuk mennggambarkan karakteristik metakognisi peserta didik di dalam melakukan pemecahan masalah ditinjau dari tipe kepribadian peserta didik tersebut.

\section{Subjek Penelitian}

Peserta didik SMK Kelas XII Jurusan TITL (Teknik Instalasi Tenaga Listrik) dengan jumlah peserta didik sebanyak 29 orang digunakan sebagai subjek penelitian ini.

\section{Prosedur Penelitian}

Langkah-langkah yang dilakukan peneliti dalam penelitian ini adalah:

1. Observasi Pendahuluan

a. Observasi ke sekolah tempat penelitian agar memperoleh informasi mengenai data peserta didik serta karakteristik peserta didik.

b. Menentukan kelas subjek penelitian berdasarkan pertimbangan dari guru matematika.

2. Pelaksanaan Penelitian

Pelaksanaan penelitian ini terdiri dari beberapa tahap yaitu:

a. Tahap persiapan

Penyusunan 4 (empat) instrumen penelitian yaitu lembar tes pemecahan masalah matematika, lembar kuesioner tipe kepribadian, lembar kuesioner metakognisi, dan pedoman wawancara.

b. Tahap pelaksanaan penelitian

1) Memberikan lembar tes pemecahan masalah melalui grup whatsapp

2) Memberikan kuesioner tipe kepribadian melalui grup whatsapp

3) Memberikan kuesioner metakognisi melalui grup whatsapp 
4) Melakukan wawancara online melalui aplikasi zoom

c. Tahap analisis data

1) Menganalisis lembar jawaban untuk tes pemecahan masalah matematika

2) Menganalisis kuesioner tipe kepribadian untuk mengetahui kepribadian peserta didik

3) Menganalisis kuesioner metakognisi untuk mengetahui karakteristik metakognisi peserta didik

4) Menganalisis hasil wawancara untuk memperoleh informasi mengenai kemampuan metakognisi peserta didik di dalam melakukan proses pemecahan masalah matematika

5) Melakukan pembahasan dari hasil penelitian

6) Penarikan kesimpulan

\section{Instrumen Penelitian}

Tiga Instrumen yang digunakan di penelitian ini yaitu lembar tes kemampuan pemecahan masalah, lembar ter kepribadian Holland, dan Lembar kuesioner metakognisi.

\section{Lembar Tes Pemecahan Masalah}

Lembar tes kemampuan dalam menyelesaikan masalah matematika terdiri dari 4 soal uraian. Soal tes diberikan agar diperoleh jawaban peserta didik secara tertulis. Pada soal tes diberikan lembar jawaban khusus yang mengacu pada indikator pemecahan masalah matematika.

\section{Lembar Tes Tipe Kepribadian Holland}

Kuesioner tipe kepribadian yang digunakan memodifikasi dari beberapa tes inventori minat Holland yang dikembangkan dari teori model minat. Kuesioner ini disusun oleh Drs. Wahid Suharmawan, M., Pd. Kuesioner tipe kepribadian memiliki 216 butir pertanyaan

Tabel 1. Kisi-Kisi Indikator Kuesioner John L. Holland

\begin{tabular}{|c|l|c|c|}
\hline $\begin{array}{c}\text { Komponen } \\
\text { Holland }\end{array}$ & \multicolumn{1}{|c|}{ Indikator } & No. Item & Jumlah \\
\hline \multirow{3}{*}{ Realistic } & Aktivitas & $1-11$ & 11 \\
\cline { 2 - 4 } & Kompetensi/Kemampuan/Keterampilan & $67-77$ & 11 \\
\cline { 2 - 4 } & Pekerjaan & $133-146$ & 14 \\
\hline \multirow{3}{*}{ Investigative } & Aktivitas & $12-22$ & 11 \\
\cline { 2 - 4 } & Kompetensi/Kemampuan/Keterampilan & $78-88$ & 11 \\
\cline { 2 - 4 } & Pekerjaan & $147-160$ & 14 \\
\hline \multirow{3}{*}{ Srtistic } & Aktivitas & $23-33$ & 11 \\
\cline { 2 - 4 } & Kompetensi/Kemampuan/Keterampilan & $89-99$ & 11 \\
\cline { 2 - 4 } & Pekerjaan & $161-174$ & 14 \\
\hline \multirow{3}{*}{ Enterprising } & Aktivitas & $34-44$ & 11 \\
\cline { 2 - 4 } & Kompetensi/Kemampuan/Keterampilan & $100-110$ & 11 \\
\cline { 2 - 4 } & Pekerjaan & $175-188$ & 14 \\
\cline { 2 - 4 } & Aktivitas & $45-55$ & 11 \\
\hline
\end{tabular}




\begin{tabular}{|l|l|c|c|}
\hline & Pekerjaan & $189-202$ & 14 \\
\hline \multirow{3}{*}{ Conventional } & Aktivitas & $56-66$ & 11 \\
\cline { 2 - 4 } & Kompetensi/Kemampuan/Keterampilan & $122-132$ & 11 \\
\cline { 2 - 4 } & Pekerjaan TOTAL & $203-216$ & 14 \\
\hline \multicolumn{2}{|c|}{} & $\mathbf{2 1 6}$ \\
\hline
\end{tabular}

\section{Lembar Kuesioner Metakognisi}

Kuesioner kemampuan metakognisi diadopsi dari Schraw dan Dennison (1994) yakni Metacognitive Awareness Inventory (MAI). Kuesioner yang digunakan ini telah dimodifikasi dari aspek bahasa dan kesesuian pernyataan dengan pembelajaran matematika. Kuesioner metakognisi dalam penelitian ini memiliki 52 pernyataan.

\section{Analisis Data}

Pedoman Penskoran digunakan sebagai acuan untuk menilai tes kemampuan dalam menyelesaikan masalah. Hasil yang diperoleh peserta didik akan dikonversikan mulai dari 0 hingga 100. Kuesioner yang diberikan berupa pernyataan-pernyataan dalam bentuk pernyataan positif yang dibagi menjadi tiga kelompok pernyataan; aktivitas, kompetensi/ kemampuan/ keterampilan, dan pekerjaan. Hasil dari kuesioner ini direkapitulasi dan dianalisis dengan cara menjumlahkan butir pernyataan yang dijawab sesuai dengan kategori yang ada kemudian menentukan tipe kepribadian peserta didik dengan cara melihat nilai tertinggi dari 6 kategori kepribadian. Selanjutnya akan dipilih tipe kepribadian yang paling dominan dari 6 kategori tersebut. Sedangkan untuk mendapatkan hasil kemampuan metakognisi peserta didik, peneliti melakukan rekapitulasi dari hasil masing-masing komponen metakognisi.

\section{Teknik Analisis Data}

\section{Tes Pemecahan Masalah Matematika}

Pedoman Penskoran digunakan sebagai acuan untuk menilai tes kemampuan dalam menyelesaikan masalah Hasil yang diperoleh dikonversikan mulai dari 0 hingga 100.

\section{Kuesioner Tipe Kepribadian}

Hasil dari kuesioner ini direkapitulasi dan dianalisis dengan cara menjumlahkan butir pernyataan yang dijawab sesuai dengan kategori yang ada kemudian menentukan tipe kepribadian peserta didik dengan cara melihat nilai tertinggi dari 6 kategori kepribadian. Selanjutnya akan dipilih tipe kepribadian yang paling dominan dari 6 kategori tersebut.

\section{Kuesioner Metakognisi}

Sedangkan untuk mendapatkan hasil kemampuan metakognisi peserta didik, peneliti melakukan rekapitulasi dari hasil masing-masing komponen metakognisi. Tingkat kemampuan metakognisi dari peserta didik, dapat di uraikan sebagai berikut: 
a. Menghitung skor setiap aspek kemampuan metakognisi peserta didik

$$
\text { Skor Aspek }=\frac{\text { Total skor setiap aspek } X 100}{\text { Banyak item setiap aspek }}
$$

b. Menghitung tingkat kemampuan metakognisi setiap peserta didik

$$
\text { Skor Peserta Didik }=\frac{\sum \text { Skor aspek }}{\text { Total aspek }}
$$

Keterangan: Total aspek $=8$

c. Menghitung rata-rata tingkat kemampuan peserta didik

$$
P=\frac{\sum \text { Skor peserta didik }}{\text { Banyak peserta didik }}
$$

Untuk menentukan tingkat kemampuan metakognisi peserta didik didasarkan pada kriteria dan penggolongannya sebagai berikut:

Tabel 2. Interval Tingkat Kemampuan Metakognisi

\begin{tabular}{|c|c|}
\hline Tinggi & $>75$ \\
\hline Sedang & $61-75$ \\
\hline Rendah & $\leq 60$ \\
\hline
\end{tabular}

Sumber: Schraw dan Dennison (1994: 470)

Interval pada tabel diatas berguna dalam mengetahui tingkat kemampuan metakognisi peserta didik. Hal ini perlu dilakukan karena kemampuan yang mereka miliki berada di tingkat yang berbeda-beda.

\section{HASIL DAN PEMBAHASAN}

\section{Analisis Lembar Kuesioner Tipe Kepribadian}

Data yang terkumpul dari kuesioner ini adalah skor tiap pernyataan kuesioner tipe kepribadian peserta didik. Kuesioner tersebut diisi oleh seluruh kelas XII-TITL 1 sebanyak 29 peserta didik. Adapun hasil akhir rekapitulasi kuesioner tipe kepribadian yang akan disajikan pada grafik berikut ini.

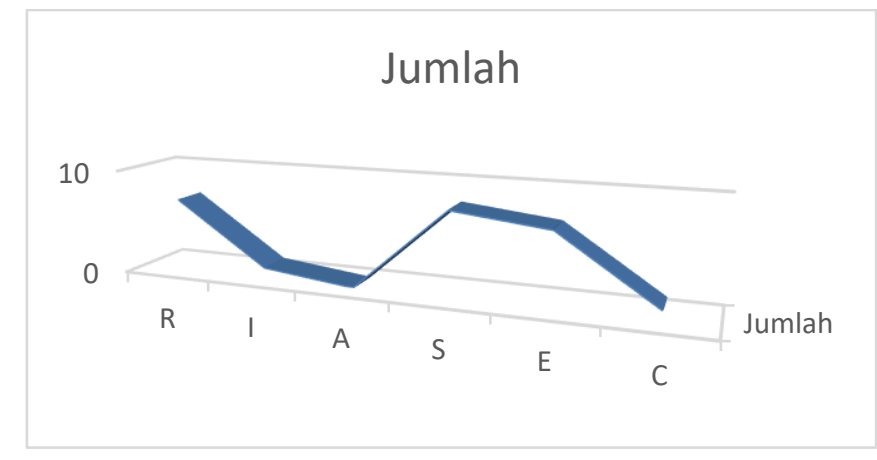

Gambar 1. Rekapitulasi Hasil Kuesioner RIASEC

Berdasarkan hasil rekapitulasi tipe kepribadian pada gambar 1 dari 29 peserta didik, terdapat peserta 
didik dengan tipe kepribadian realistik sebanyak 7 peserta didik, peserta didik dengan tipe kepribadian intelektual sebanyak 1 peserta didik, peserta didik dengan tipe kepribadian sosial sebanyak 8 peserta didik, peserta didik dengan tipe kepribadian enterprisining sebanyak 7 peserta didik, peserta didik dengan tipe kepribadian konvensional sebanyak 1 peserta didik, peserta didik dengan tipe kepribadian realistik dan artistik sebanyak 1 peserta didik, peserta didik dengan tipe kepribadian intelektual dan konvensional sebanyak 1 peserta didik, peserta didik dengan tipe kepribadian sosial dan enterprisining sebanyak 1 peserta didik, peserta didik dengan tipe kepribadian realistik, sosial, dan enterprisining sebanyak 1 peserta didik, dan peserta didik dengan tipe kepribadian realistik, artistik, dan sosial sebanyak 1 peserta didik. Berdasarkan hasil tersebut maka akan diambil peserta didik dengan tipe kepribadian dominan yaitu tipe kepribadian sosial sebanyak 8 peserta didik.

\section{Analisis Kuesioner Metakognisi}

Berdasarkan hasil rekapitulasi kuesioner metakognisi pada gambar 1 dari 29 peserta didik yang telah mengisi kuesioner di google formulir, terdapat peserta didik dengan tingkat metakognisi tinggi sebanyak 12 peserta didik, peserta didik dengan tingkat metakognisi sedang sebanyak 7 peserta didik, dan peserta didik dengan tingkat metakognisi rendah sebanyak 10 peserta didik.

Analisis Tes Pemecahan Masalah Matematika Dengan Subjek Tipe Kepribadian Sosial berdasarkan Kemampuan Metakognisi Kategori Tingkat Tinggi

Analisis dilakukan terhadap 4 soal yang diberikan dengan memperhatikan tahapan pemecahan masalah, aktivitas dan proses metakognisi. Berdasarkan tahapan pemecahan masalah yang pertama yaitu memahami masalah dengan mengidentifikasi dan mengklasifikasikan masalah, subjek ALF sadar terhadap proses dan hasil berfikir dalam mengembangkan perencanaan saat memahami masalah. Hal tersebut dapat dilihat dari hasil pengerjaan 4 soal tersebut dan wawancara yang telah dilakukan. Dari 4 soal tersebut, subjek ALF mampu mengidentifikasi apa yang diketahui dan apa yang ditanya. Subjek mengidentifikasi soal 1 dan 2 adalah permasalahan yang berhubungan dengan turunan aljabar, soal 3 diidentifikasi permasalahan yang berhubungan dengan nilai maksimum dan minimum, serta soal 4 sebagai permasalahan banyak barang yang diproduksi. Berikut ini diberikan hasil pada 4 soal tersebut.



Gambar 2. Hasil Pengerjaan Subjek ALF pada Tahap 1 Pemecahan Masalah 
Dari gambar 2 dapat dianalisis bahwa subjek ALF mampu memikirkan rencana tindakan, membangun alternatif penyelesaian, hal ini menunjukkan subjek ALF dapat melaksanakan tahap pemecahan masalah yang kedua. Rencana tindakan yang diberikan pada semua nomor adalah rencana tindakan yang tepat, yaitu rencana untuk menentukan turunan aljabar, nilai maksimum dan minimum, serta banyak barang yang diproduksi. Berdasarkan hasil wawancara yang dilakukan pada subjek, hal menarik yang ditemukan adalah penulisan untuk sesuatu yang ditanyakan pada soal nomor 1 dan 2 adalah penyimbolan $f^{\prime}(x)$ untuk turunan, namun dalam merencanakan tindakan selanjutnya subjek menggunakan symbol $\frac{d}{d x}$. Pada soal no 3, subjek hanya mampu mengidentifikasi permasalahan "nilai maksimum dan minimum" namun kesulitan dalam merencanakan tindakannya. Sedangkan untuk soal no 4, subjek mampu merencanakan tindakan dari permasalahan yang ada yaitu dengan memberikan simbol/variabel dalam soal yang diberikan yaitu $u(x)$.

Pada tahap pemecahan masalah yang ketiga yaitu melaksanakan rencana tindakan dengan memilih strategi penyelesaian, subjek ALF mampu melaksanakan 3 soal dengan benar, yaitu soal 1, 2, dan 4. Sedangkan pada soal nomor 3 mengalami kesalahan dalam melaksanakan rencana. Berikut ini adalah hasil pelaksanaan tahap 3 dalam pemecahan masalah.

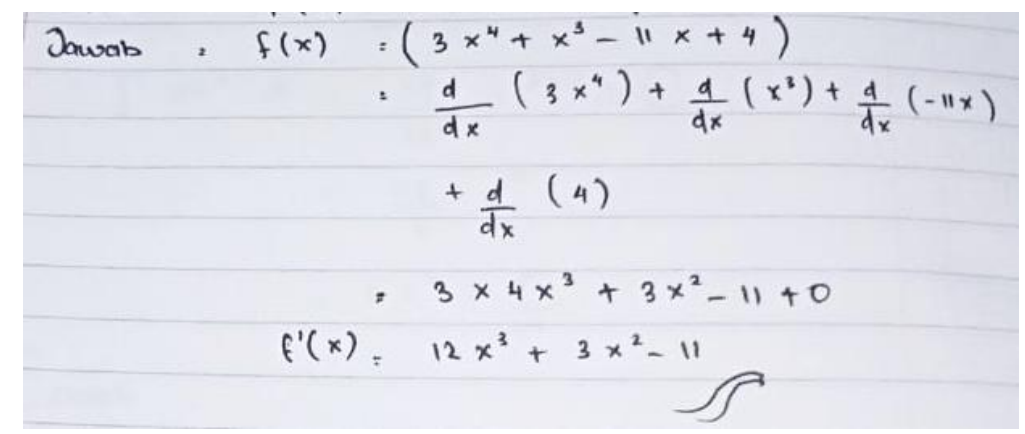

Gambar 3. Penyelesaian Subjek ALF No. 1

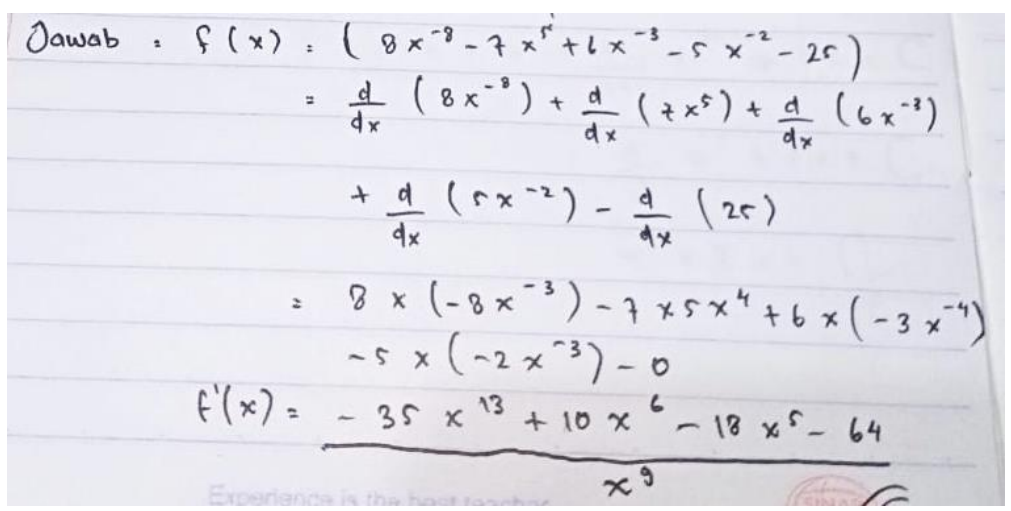

Gambar 4. Penyelesaian Subjek ALF No. 2 




Gambar 5. Penyelesaian Subjek ALF No. 3

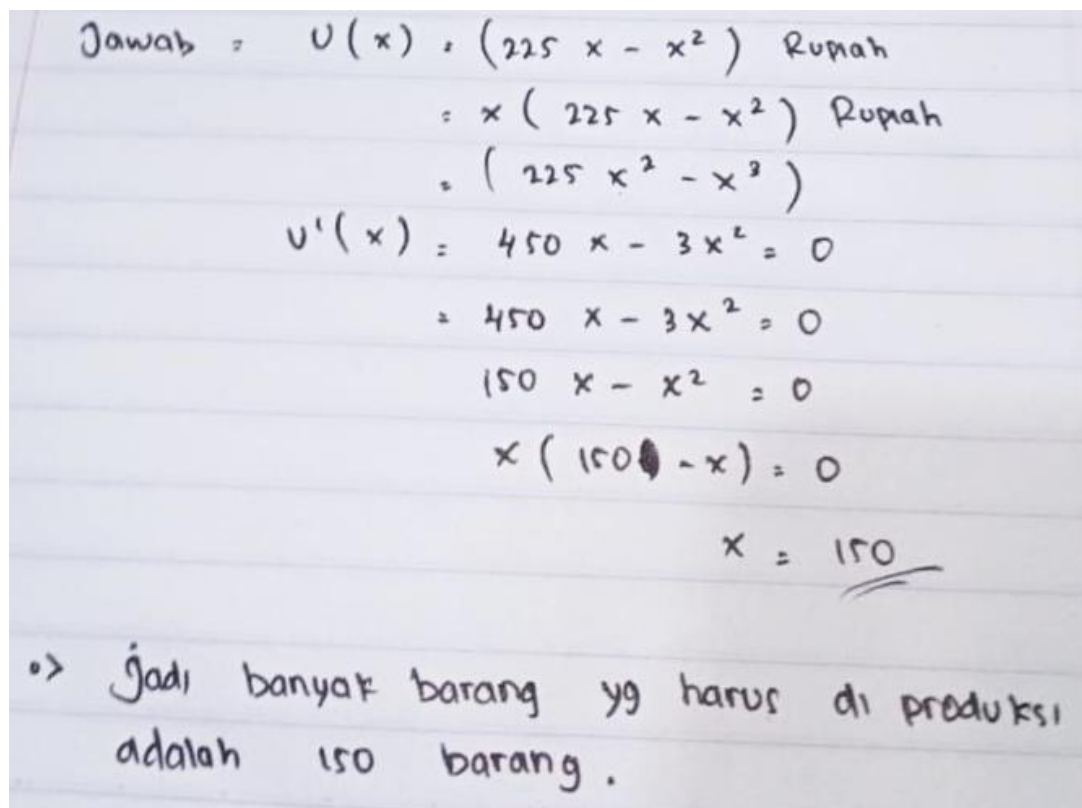

Gambar 6. Penyelesaian Subjek ALF No. 4

Berdasarkan hasil pengerjaan pada gambar 3 sampai gambar 6, pada soal no 1 dan 2 subjek menggunakan aturan turunan aljabar pada operasi penjumlahan dan pengurangan dengan simbol $\frac{d}{d x}$. Subjek mengubah bentuk operasi pengurangan dengan bentuk operasi penjumlahan bilangan negatif. Pada soal no 3, subjek tidak tepat dalam melaksanakan rencana tindakan, terlihat bahwa subjek memahami untuk mencari nilai $x$ yang dicari namun konsep yang digunakan tidak tepat. Sedangkan pada soal no 4, subjek mampu melaksanakan rencana tindakan dan memperoleh hasil yang tepat yaitu banyak barang yang harus diproduksi. Selain itu, subjek juga menggunakan simbol turunan yang berbeda dengan tindakan pada soal no 1 dan 2 serta dalam proses pengerjaan, subjek menyelesaikan secara terurut dan detail dalam melakukan perhitungan, namun pada soal lainnya subjek menyelesaikan tanpa melakukan perhitungan yang detail.

Pada tahap pemecahan masalah yang keempat yaitu mengevaluasi dan meneliti kembali bagaimana penyelesaian terbaik, subjek ALF merasa perlu melakukan pengecekan. Berdasarkan hasil wawancara diketahui, subjek ALF menggunakan cara yang berbeda dalam melakukan perhitungan operasi pengurangan yang ada pada soal no 1 dan 2 . Pada soal no 1 terlihat subjek merubah operasi pengurangan 
menjadi operasi penjumlahan negatif dan dari itu diperoleh keyakinan hasil yang sama jika tidak dirubah menjadi operasi penjumlahan. Selain itu, subjek juga melakukan cek pada soal no 4 dan menggunakan simbol turunan yang berbeda dari soal no 1 dan 2 . Secara garis besar subjek berpendapat bahwa ada cara lain dalam menyelesaikan soal tersebut namun subjek tidak bisa menunjukkan cara tersebut. Sedangkan untuk soal no 3, subjek mengalami kesulitan mengecek karena subjek mengalami kesulitan menentukan rencana tindakan yang digunakan untuk soal nomer tersebut. Terlihat bahwa pada soal no 3 subjek tidak tepat dalam menyelesaikan soal tersebut.

Analisis Tes Pemecahan Masalah Matematika Dengan Subjek Tipe Kepribadian Sosial berdasarkan Kemampuan Metakognisi Kategori Tingkat Rendah

Analisis dilakukan terhadap 4 soal yang diberikan dengan memperhatikan tahapan pemecahan masalah, aktivitas dan proses metakognisi. Berdasarkan tahapan pemecahan masalah yang pertama yaitu memahami masalah dengan mengidentifikasi dan mengklasifikasikan masalah, subjek DTP sadar terhadap proses dan hasil berfikir dalam mengembangkan perencanaan saat memahami masalah. Hal tersebut dapat dilihat dari hasil pengerjaan 4 soal tersebut dan wawancara yang dilakukan. Dari 4 soal tersebut, subjek tidak mampu mengidentifikasi apa yang diketahui dan apa yang ditanya pada soal no 1, 2, dan 3. Sedangkan pada soal no 4 mampu mengidentifikasi apa yang diketahui dan apa yang ditanya. Berikut ini diberikan hasil identifikasi pada 4 soal tersebut.

Dapat dianalisis bahwa subjek tidak mampu memikirkan rencana tindakan, membangun alternatif penyelesaian, hal ini menunjukkan subjek DTP tidak dapat melaksanakan tahap pemecahan masalah yang kedua. Berdasarkan hasil wawancara yang dilakukan pada subjek, hal menarik yang ditemukan adalah subjek tidak terbiasa untuk menuliskan apa yang diketahui dan ditanya namun terkadang bisa menyelesaikan soal yang diberikan. Pada soal no 4, subjek mampu merencanakan tindakan dari permasalahan yang ada dengan menuliskan apa yang diketahui dan ditanya.

Pada tahap pemecahan masalah yang ketiga yaitu melaksanakan rencana tindakan dengan memilih strategi penyelesaian, subjek DTP tidak mampu menyelesaikan dengan benar 2 soal, yaitu soal 1 dan 2 . Sedangkan pada soal nomor 3 dan 4 subjek mampu menyelesaikan permasalahan.

Berdasarkan hasil pengerjaan pada soal no 1 dan 2 subjek menggunakan aturan yang salah. Subjek berpendapat karena variabel $x$ tidak diketahui maka dia mensubtitusikan nilai 0 pada variabel $x$. Pada soal no 3, subjek tepat dalam melaksanakan rencana tindakan, terlihat bahwa subjek memahami untuk mencari nilai $x$ yang dicari dan aturan subtitusi yang digunakan ketika variabel $\mathrm{x}$ telah ditemukan. Sedangkan pada soal no 4 , subjek mampu melaksanakan rencana tindakan dan memperoleh hasil yang tepat yaitu banyak barang yang harus diproduksi. Dari wawancara yang dilakukan, subjek terbiasa dengan soal yang berhubungan dengan aplikasi/penerapan namun secara teoritis kurang diminati. 
Pada tahap pemecahan masalah yang keempat yaitu mengevaluasi dan meneliti kembali bagaimana penyelesaian terbaik, subjek DTP tidak melakukan pengecekan. Secara garis besar subjek berpendapat ada cara lain dalam menyelesaikan soal tersebut namun subjek tidak bisa menunjukkan cara tersebut. Sedangkan untuk soal no 1 dan 2, subjek mengalami kesulitan menentukan rencana tindakan yang digunakan untuk soal nomer tersebut. Terlihat bahwa pada soal no 1 dan 2 subjek tidak tepat dalam menyelesaikan soal tersebut.

Deskripsi Karakteristik Metakognisi Tingkat Tinggi

Tabel 3. Deskripsi Karakteristik Metakognisi Tingkat Tinggi

\begin{tabular}{|c|c|c|c|c|}
\hline $\begin{array}{c}\text { Langkah } \\
\text { pemecahan } \\
\text { masalah }\end{array}$ & Perencanaan & Pemantauan & Evaluasi/Refleksi & $\begin{array}{c}\text { Karakteristik } \\
\text { Metakognisi }\end{array}$ \\
\hline $\begin{array}{l}\text { Memahami } \\
\text { masalah }\end{array}$ & $\begin{array}{l}\text { - } \text { membaca } \\
\text { soal agar } \\
\text { memahami } \\
\text { soal } \\
\text { - mengetahui } \\
\text { yang } \\
\text { diketahui } \\
\text { serta yang } \\
\text { ditanyakan } \\
\text { - mengetahui } \\
\text { hubungan } \\
\text { antar simbol }\end{array}$ & $\begin{array}{l}\text { Memahami } \\
\text { masalah yang } \\
\text { diketahui dan } \\
\text { ditanyakan } \\
\text { Mengoneksikan } \\
\text { informasi- } \\
\text { informasi yang } \\
\text { ada: } \\
\text { - Mengoneksika } \\
\text { n symbol } \\
\text { turunan } \\
\text { f(x) dan } \frac{d}{d x} \\
\text { - Mengoneksika } \\
\mathrm{n} \\
\text { turunan aturan } \\
\text { aljabar pada } \\
\text { operasi } \\
\text { penjumlahan } \\
\text { dan } \\
\text { pengurangan } \\
\text { - Menghubungk } \\
\text { an aturan } \\
\text { turunan } \\
\text { pertama dan } \\
\text { kedua dalam } \\
\text { aplikasi } \\
\text { turunan } \\
\text { - Menghubungk } \\
\text { an aturan } \\
\text { substitusi } \\
\text { dalam aplikasi } \\
\text { turunan }\end{array}$ & $\begin{array}{l}\text { Melakukan evaluasi } \\
\text { bahwa apakah yang } \\
\text { diketahui sudah } \\
\text { lengkap dan benar } \\
\text { Melakukan evaluasi } \\
\text { apakah masalah yang } \\
\text { ditanya sudah benar }\end{array}$ & $\begin{array}{l}\text { - Sadar bahwa di } \\
\text { dalam } \\
\text { memecahkan } \\
\text { masalah, harus } \\
\text { memahami apa } \\
\text { yang diketahui } \\
\text { dan ditanya } \\
\text { dengan cara } \\
\text { membaca } \\
\text { - Memiliki rasa } \\
\text { perlunya untuk } \\
\text { menulis yang } \\
\text { diketahui serta } \\
\text { ditanyakan } \\
\text { - Melakukan } \\
\text { peninjauan } \\
\text { kembali tentang } \\
\text { kebenaran aturan } \\
\text { yang digunakan }\end{array}$ \\
\hline
\end{tabular}




\begin{tabular}{|c|c|c|c|c|}
\hline $\begin{array}{l}\text { Merencanaka } \\
\text { n Pemecahan } \\
\text { Masalah }\end{array}$ & $\begin{array}{l}\text { - } \text { Berpikir cara } \\
\text { memecahkan } \\
\text { masalah. } \\
\text { - Sadar untuk } \\
\text { memilih } \\
\text { rumus atau } \\
\text { aturan atau } \\
\text { simbol yang } \\
\text { digunakan }\end{array}$ & $\begin{array}{l}\text { - Caranya } \\
\text { dengan } \\
\text { memecah } \\
\text { menggunakan } \\
\text { aturan turunan } \\
\text { dalam operasi } \\
\text { penjumlahan } \\
\text { dan } \\
\text { pengurangan } \\
\text { - Caranya } \\
\text { dengan } \\
\text { menggunakan } \\
\text { aturan turunan } \\
\text { pertama dan } \\
\text { kedua untuk } \\
\text { penerapan } \\
\text { turunan }\end{array}$ & $\begin{array}{l}\text { - } \text { Menyadari jika } \\
\text { permasalahan } \\
\text { diselesaiakan } \\
\text { dengan aturan } \\
\text { turunan, aturan } \\
\text { menyelesaikan } \\
\text { nilai maksimum } \\
\text { dan minimum, serta } \\
\text { aturan subtitusi. }\end{array}$ & $\begin{array}{l}\text { - Sadar terhadap } \\
\text { langkah-langkah } \\
\text { yang akan } \\
\text { dilakukan } \\
\text { - Sadar akan aturan } \\
\text { yang digunakan } \\
\text { - Dapat memilah } \\
\text { aturan dan simbol } \\
\text { yang paling tepat }\end{array}$ \\
\hline $\begin{array}{l}\text { Menyelesaik } \\
\text { an masalah } \\
\text { sesuai } \\
\text { rencana }\end{array}$ & $\begin{array}{l}\text { Melaksanakan } \\
\text { merasa perlu } \\
\text { untuk } \\
\text { mendetailkan } \\
\text { pengerjaan }\end{array}$ & $\begin{array}{l}\text { Melakukan } \\
\text { penyelesaian } \\
\text { dengan cermat }\end{array}$ & $\begin{array}{l}\text { Setelah } r \text { selesai } \\
\text { merasa tidak perlu } \\
\text { mengecek } \\
\text { kebenaranya } \\
\text { khususnya no } 3 \\
\text { merasa ada yang } \\
\text { kurang namun tidak } \\
\text { menemukan } \\
\text { penyelesaian lainnya. }\end{array}$ & $\begin{array}{l}\text { Melakukan } \\
\text { penyelesaian/ } \\
\text { perhitungan }\end{array}$ \\
\hline $\begin{array}{l}\text { Mengevaluas } \\
\mathrm{i} \text { dan } \\
\text { memeriksa } \\
\text { kembali }\end{array}$ & $\begin{array}{l}\text { Menyadari jika } \\
\text { perlu } \\
\text { memeriksa } \\
\text { kembali }\end{array}$ & $\begin{array}{l}\text { Meneliti } \\
\text { perhitungan } \\
\text { pada } \\
\text { jawabannya }\end{array}$ & $\begin{array}{l}\text { Merasa perlu adanya } \\
\text { pengecekan ulang } \\
\text { dari awal, apa yang } \\
\text { diketahu, ditanya, } \\
\text { dan aturan yang } \\
\text { digunakan }\end{array}$ & $\begin{array}{l}\text { Sadar bahwa ada } \\
\text { cara lain, tetapi } \\
\text { tidak } \\
\text { menunjukkannya }\end{array}$ \\
\hline
\end{tabular}

Deskripsi Karakteristik Metakognisi Tingkat Rendah

Tabel 5. Deskripsi Karakteristik Metakognisi Tingkat Rendah

\begin{tabular}{|c|c|c|c|c|}
\hline $\begin{array}{c}\text { Langkah } \\
\text { pemecahan } \\
\text { masalah }\end{array}$ & Perencanaan & Pemantauan & Evaluasi/Refleksi & $\begin{array}{c}\text { Karakteristik } \\
\text { Metakognisi }\end{array}$ \\
\hline $\begin{array}{l}\text { Memahami } \\
\text { masalah }\end{array}$ & $\begin{array}{l}\text { - } \text { membaca } \\
\text { soal agar } \\
\text { memahami } \\
\text { soal. } \\
\text { - mengetahui } \\
\text { yang } \\
\text { diketahui }\end{array}$ & $\begin{array}{l}\text { Memahami } \\
\text { masalah yang } \\
\text { diketahui dan } \\
\text { ditanyakan } \\
\text { Mengoneksikan } \\
\text { informasi- }\end{array}$ & $\begin{array}{l}\text { Mengevaluasi apakah } \\
\text { masalah yang ditanya } \\
\text { sudah benar }\end{array}$ & $\begin{array}{l}\text { - Tidak } \\
\text { Menyadari } \\
\text { bahwa dalam } \\
\text { memecahkan } \\
\text { masalah, harus } \\
\text { memahami apa } \\
\text { yang diketahui } \\
\text { serta ditanya }\end{array}$ \\
\hline
\end{tabular}




\begin{tabular}{|c|c|c|c|c|}
\hline & $\begin{array}{l}\text { serta yang } \\
\text { ditanyakan } \\
\text { - mengetahui } \\
\text { hubungan } \\
\text { antar simbol }\end{array}$ & \begin{tabular}{|l|} 
informasi yang \\
ada: \\
- Mengoneksika \\
n aturan \\
turunan \\
pertama dan \\
kedua dalam \\
aplikasi \\
turunan \\
- Mengoneksika \\
n aturan \\
substitusi \\
dalam aplikasi \\
turunan
\end{tabular} & & $\begin{array}{l}\text { dengan cara } \\
\text { membaca } \\
\text { - Tidak memiliki } \\
\text { rasa perlu untuk } \\
\text { menulis yang } \\
\text { diketahui serta } \\
\text { ditanyakan } \\
\text { - Melakukan } \\
\text { peninjauan } \\
\text { kembali tentang } \\
\text { kebenaran aturan } \\
\text { yang digunakan }\end{array}$ \\
\hline $\begin{array}{l}\text { Merencanaka } \\
\text { n Pemecahan } \\
\text { Masalah }\end{array}$ & $\begin{array}{l}\text { - Berfikir cara } \\
\text { memecahkan } \\
\text { masalah. } \\
\text { - Sadar } \\
\text { memilih } \\
\text { rumus atau } \\
\text { aturan yang } \\
\text { digunakan }\end{array}$ & $\begin{array}{l}\text { - Caranya } \\
\text { dengan } \\
\text { menggunakan } \\
\text { aturan turunan } \\
\text { pertama dan } \\
\text { kedua untuk } \\
\text { penerapan } \\
\text { turunan }\end{array}$ & $\begin{array}{l}\text { - Tidak menyadari } \\
\text { jika permasalahan } \\
\text { diselesaiakan } \\
\text { dengan aturan } \\
\text { turunan, } \\
\text { - Menyadari aturan } \\
\text { menyelesaikan } \\
\text { nilai maksimum } \\
\text { dan minimum, serta } \\
\text { aturan subtitusi. }\end{array}$ & $\begin{array}{l}\text { - Sadar akan } \\
\text { langkah-langkah } \\
\text { yang dilakukan } \\
\text { - Sadar terhadap } \\
\text { aturan yang akan } \\
\text { digunakan } \\
\text { - Dapat memilih } \\
\text { simbol dan aturan } \\
\text { yang paling tepat }\end{array}$ \\
\hline $\begin{array}{l}\text { Menyelesaik } \\
\text { an Masalah } \\
\text { sesuai } \\
\text { rencana }\end{array}$ & $\begin{array}{l}\text { Melaksanakan } \\
\text { merasa perlu } \\
\text { untuk } \\
\text { mendetailkan } \\
\text { proses } \\
\text { pengerjaan }\end{array}$ & $\begin{array}{l}\text { Melakukan } \\
\text { penyelesaian } \\
\text { dengan cermat } \\
\text { untuk } \\
\text { permasalahan } \\
\text { aplikasi turunan }\end{array}$ & $\begin{array}{lr}\text { Setelah } & \text { selesai } \\
\text { merasa tidak perlu } \\
\text { mengecek } & \\
\text { kebenaranya } & \end{array}$ & $\begin{array}{l}\text { - } \begin{array}{l}\text { Melakukan } \\
\text { penyelesaian atau } \\
\text { perhitungan }\end{array} \\
\text { - Memberikan } \\
\text { kesimpulan } \\
\text { dalam pengerjaan }\end{array}$ \\
\hline $\begin{array}{l}\text { Mengevaluas } \\
\mathrm{i} \text { dan } \\
\text { memeriksa } \\
\text { kembali }\end{array}$ & $\begin{array}{l}\text { Tidak } \\
\text { menyadari jika } \\
\text { perlu } \\
\text { memeriksa } \\
\text { kembali }\end{array}$ & \begin{tabular}{|l|} 
Langsung \\
berhenti setelah \\
selesai \\
mengerjakan
\end{tabular} & $\begin{array}{l}\text { Tidak merasa perlu } \\
\text { adanya pengecekan } \\
\text { ulang dari awal, apa } \\
\text { yang diketahu, } \\
\text { ditanya, dan aturan } \\
\text { yang digunakan }\end{array}$ & $\begin{array}{l}\text { Sadar ada cara lain, } \\
\text { tetapi tidak dapat } \\
\text { menunjukkannya }\end{array}$ \\
\hline
\end{tabular}

\section{KESIMPULAN}

Dari enam tipe kepribadian tersebut terdapat tipe kepribadian dominan yaitu kepribadian sosial yang diambil sebagai subjek penelitian dengan tingkat kemampuan metakognisi tinggi, sedang, dan rendah. Karakteristik metakognisi tingkat tinggi dan rendah pada tipe kepribadian social memiliki perbedaan yang terlihat pada kesadaran untuk mengidentifikasi informasi yang diketahui dan ditanya. 
Pada tingkat tinggi, tipe kepribadian social menyadari perlunya identifikasi sehingga mampu merencanakan tindakan secara tepat, namun berkebalikan dengan metakognisis tingkat rendah.

\section{DAFTAR PUSTAKA}

Agustina, R. 2013. Tesis: Proses Berpikir Siswa dalam Penyelesaian Masalah Aplikasi Turunan Fungsi Ditinjau dari Tipe Kepribadian Tipologi Hippocrates Galenus. Surakarta: Universitas Sebelas Maret.

Alfiyah, N. \& Siswono, T. Y. E. 2014. Identifikasi Kesulitan Metakognisi Siswa dalam Memecahkan Masalah Matematika. Jurnal Ilmiah Pendidikan Matematika Vol 3 No 2 Hal 131-138.

Anggo, Mustamin. 2011. Perlibatan Metakognisi dalam Pemecahan Masalah Matematika. Edumatica Vol 1 No 1 Hal 25-32.

Arikunto, S. 2006. Metode Penelitian Kualitatif. Jakarta: Bumi Aksara

Arikunto, S. 2013. Prosedur Penelitian: Suatu Pendekatan Praktik. Jakarta: Rineka Cipta

Bulu, V. R. (2015). Kesulitan Metakognisi Siswa dalam Memecahkan Masalah Matematika pada Materi Peluang Ditinjau Dari Tipe Kepribadian Tipologi Hippocrates-Galenus Kelas XI MIA 1 SMA Negeri 1 Soe Di Nusa Tenggara Timur. Tesis. Surakarta: Universitas Sebelas Maret.

Chairani, Zahra. 2016. Metakognisi Siswa dalam Pemecahan Masalah Matematika. Yogyakarta: DEEPUBLISH.

Chrobak, R., 1999, Metacognition and Didactic Tools in Higher Education, Comahue National University, Boenos Aires

Cohors-Fresenborg, E., and Kaune, C., 2007, Modelling Classroom Discussion and Categorizing Discursive and Metacognitive Activities, In Proceeding of CERME 5, 1180 - 1189.

Depdiknas. 2006. Permendiknas No. 22 Tahun 2006 Tentang Standar Isi. Jakarta: Depdiknas

Desoete, J.A. (2007). Evaluating and Improving the Mathematics Teaching-Learning Process Through Metacognition, Electronic Journal of Research in Educational Psychology. N. 13 Vol 5, ISSN. 1696-2095.

Faslah, Fachorul. 2018. Kemampuan Metakognitif Peserta Didik Pada Penerapan Pendekatan Realistic Mathematics Education (RME) Pada Pokok Bahasan Barisan Dikelas XI-IPA 4 SMA Negeri 1 Cerme. Skripsi. Gresik: Universitas Muhammadiyah Gresik.

Fauziyah, Nafisatul. 2011. Identifikasi Karakteristik Metakognisi Siswa dalam Memecahkan Masalah Matematika di Kelas VII-F SMPN 1 Gresik. Skripsi. Surabaya: UNESA

Fitria, C., Sujadi, I., dan Subanti, S. (2016). Analisis Kesulitan Metakognisi Siswa dalam Memecahkan Masalah Sistem Pertidaksamaan Linear Dua Variabel Ditinjau dari Tipe Kepribadian Guardian, Arisan, Rational, dan Idealist Kelas X SMKN 1 Jombang. Jurnal Elektronik Pembelajaran Matematika. 4 (9), 824-835.

Flavell, J. (1979). Metacognition and Cognitive Monitoring : A New Area of Cognitive Development Inquiry. American Paychologist, Standford University. 34 (10), 906-911. 
Gay, G. 2002. The Nature of Metacognition, Adaptive Technology Resource Centre (Legal Notice).

Hadi, S., \& Radiyatul. (2014). Metode Pemecahan Masalah Menurut Polya untuk Mengembangkan Kemampuan Siswa dalam Pemecahan Masalah Matematis di Sekolah Menengah Pertama. EDU-MAT Jurnal Penddikan Matematika Volume 2 Nomor 1.

Hasanah. 2013. Analisis Proses Berpikir Siswa dalam Memecahkan Masalah Matematika Ditinjau dari Tipe Kepribadian Extrovert - Introvert. Surakarta: Universitas Sebelas Maret.

Laurens, Theresia. 2009. Penjenjangan Metakognisi Siswa. Disertasi Pascasarjana Program Studi Pendidikan Matematika. Universitas Surabaya.

Lee, M., and Baylor, A. L.. 2006. Designing Metacognitive Maps for Web-Based Learning, Educational Technology \& Society. 9 (1). $344-348$

Mahromah, Laily Agustina dan Janet Trineke Manoy. 2013. Identifikasi Tingkat Metakognisi Siswa Dalam Memecahkan Masalah Matematika Berdasarkan Perbedaan Skor Matematika. Universitas Surabaya.

Mulbar, Usman. 2008. Metakognisi Siswa dalam Menyelesaikan Masalah Matematika. Makalah Pendidikan. FMIPA UNM Makasar.

NCTM. 2000. Principles and Standards for School Mathematics. USA: the National Councilll of Teacher Mathematics inc.

Polya, G. 1973. How to Solve It. NJ. Prisceton University Press.

Purnaningsih, N. E. \& Siswono, T. Y. E. 2014. Profil Metakognisi Siswa dalam memecahkan Masalah Matematika Ditinjau Berdasarkan Tipe Kepribadian Koleris dan Phlegmatis. Jurnal Ilmiah Pendidikan Matematika Vol 3 No 3 Hal 152-159.

Rachmady, R., Anggo, M., \& Busnawir. (2019). Analisis Metakognisi dalam Pemecahan Masalah Matematika Siswa SMP. Jurnal Pembelajaran Berpikir Matematika, 37.

Rosiani, Anggo, M., \& Saudia, M. (2019). Pengaruh Pembelajaran Berbasis Masalah Kontekstual dengan Pendekatan Metakognisi terhadap Kemampuan Pemecahan Masalah Matematika Siswa Kelas VIII SMP. Jurnal Pembelajaran Berpikir Matematika, 72.

Saputra, Wahyu Nanda Eka. 2014. Teori Holland. Skripsi. Malang: Universitas Negeri Malang.

Schoenfeld, A. H. 1992. Learning to think mathematically: Problem solving, metacognition, and sensemaking in mathematics. In D. Grouws (Ed.), Handbook for Research on Mathematics Teaching and Learning (pp. 334-370). New York: MacMillan

Schraw, G., \& Dennison, R. S. (1994). Assessing meta-cognitive awareness. Contemporary educational psychology, 19(4), 460-475.

Siswono, Tatag Y.E. 2018. Pembelajaran Matematika Berbasis Pengajuan dan Pemecahan Masalah. Bandung: Rosda.

Susanto. 2006. Metodologi Penelitian Sosial. Surakarta: UNS Press. 